\title{
PERAN AYAH DALAM MENANAMKAN SIKAP SELF ACCEPTANCE DALAM RANGKA MENCEGAH PERILAKU HOMOSEKSUAL PADA ANAK
}

\author{
ISYATUL MARDIYAH \\ Dosen Fakultas Tarbiyah dan Ilmu Kependidikan (FTIK) \\ Institut Agama Islam Negeri (IAIN) Pontianak \\ isyamar_zein@yahoo.com
}

\begin{abstract}
The role of a father in a family is not only as a leader and living-earner. However, a father also has a rule to build children personality like selfacceptance so in the next days they could be great people. Moreover, there is an assumption that one of the reason the existence of LGBT people due to lack of father's role at home. In addition, self-acceptance is one of significant factors in building one's personality and behavior. Psychological sisues such as hysteric feelings, sexual impotence, kleptomaniac, etc occurs because of lack of selfacceptance. Therefore, self-acceptance is also important for people who eager to recover from their illness since without the self-acceptance people would be in the pain, an introvert, hopeless, and isolated themselves from others.
\end{abstract}

Keywords: Roles, Father, Self-Acceptence

\section{PENDAHULUAN}

Manusia adalah mahluk individu dan sosial. Sebagai individu mereka berkata, berpikir dan bertindak sesuai dengan kemampuannya. Namun sebagai mahluk sosial, manusia memerlukan dukungan sosial (social support), dari lingkungan keluarga, maupun lingkungan masyarakatnya. Keadaan ini, kemudian menjadikan sebuah dukungan yang diberikan kepada individu memiliki interkoneksi dalam penerimaan diri (self acceptance). Sehingga mental seseorang akan bergantung pada bagaimana persepsi individu tersebut akan dukungan yang telah diterima oleh dirinya.

Beberapa studi terkait penerimaan diri menyebutkan bahwa persepsi individu akan dukungan yang tersedia lebih memiliki tingkat hubungan dengan kesehatan fisik dan mental individu, jika dibandingkan dengan dukungan yang sesunggguhnya diterima oleh individu tersebut. Dengan demikian, bagaimana individu menilai dukungan yang tersedia bagi dirinya merupakan suatu hal yang lebih penting daripada interaksi interpersonal yang sesungguhnya dilakukan. Selanjutnya, penerimaan diri merupakan suatu derajat dimana individu dapat merangkul segala karakteristik personal di dalam diri serta bersedia untuk hidup beriringan dengan lingkungan sosialnya dengan segala karakteristik tersebut. Dengan kata lain penerimaan diri (self acceptance) yang baik akan lebih memungkinkan seseorang untuk mudah menyesuaikan diri dengan orang disekitanyar. Disamping itu, individu juga dapat lebih berfokus pada aspek penghargaan diri dalam setiap situasi.

Self acceptance juga merupakan sikap dalam menilai keadaan di dalam diri secara objektif dengan menerima segala kelebihan dan kelemahan yang ada di dalam diri. Self acceptance merupakan suatu sikap dimana individu merasa puas akan setiap kualitas serta bakat yang ada di dalam diri serta mengakui segala keterbatasan yang ada. Pengakuan akan keterbatasan diri tidak disertai dengan perasaan ragu, malu dan bersalah. Sebaliknya, individu senantiasa berusaha untuk menerima diri apa adanya tanpa terkecuali. 
Terkait self acceptance yang dimaknai sebagai suatu situasi dimana individu berusaha untuk hidup secara mandiri, bergantung pada dirinya sendiri serta secara ikhlas menerima segala kelebihan dan kekurangan di dalam diri. Individu yang berhasil menerima keadaaan dirinya dengan tenang secara otomatis akan terbebas dari rasa malu, rasa bersalah, rasa rendah diri, keterbatasan diri serta terbebas dari kecemasan akan penilaian orang lain terhadap diri individu tersebut.

Individu yang memiliki self acceptance yang rendah akan merasa tidak puas terhadap diri sendiri, cenderung menyesali apa yang terjadi di masa lalu, sulit untuk membuka diri, merasa terisolasi serta frustasi dalam hubungan interpersonal sehingga tidak ada keinginan bagi individu tersebut untuk mempertahankan hubungan dengan orang lain. Sebaliknya, bagi individu yang memiliki self acceptance dalam tingkat optimal atau tinggi, maka individu tersebut akan bersikap positif terhadap diri sendin, menerima kualitas baik dan buruk pada dirinya serta memiliki sikap yang positif akan masa lau.

Dukungan sosial yang muncul pada diri individu, merupakan kepercayaan internal serta pemahaman individu mengenai adanya orang-orang sekitar yang menghargai serta mencintai individu dan dengan segenap hati bersedia untuk menolong individu apabila individu yang bersangkutan membutuhkan bantuan atau dukungan. Individu memiliki kepercayaan bahwa dirinya benar-benar dihargai, disayangi, diterima apa adanya (sense of acceptance) dan akan mendapatkan dukungan atau bantuan dari orang lain ketika dirinya membutuhkan (sense of support). Hal ini yang dapat menyokong individu untuk mengatasi segala masalah serta persoalan yang ada di dalam kehidupan.

\section{SELF ACCEPTANCE DAN HOMOSEKSUAL}

\section{Self Acceptance}

\section{a. Definisi self acceptance}

Penerimaan diri merupakan tahapan pertama dalam menemukan potensi yang ada pada diri seseorang. Tahapan ini diletakan pada urutan pertama karena sebagai tahapan yang paling penting dalam membentuk dasar dari karakter seseorang sebelum mencapai pada tahapan-tahapan selanjutnya. Self Acceptance memberikan kontribusi bagi kebahagiaan setiap individu di dalam mewujudkan kepribadian mental individu yang sehat. Sehingga, merupakan salah satu faktor penentu kebahagiaan individu. Self acceptance merupakan suatu kondisi psikologis yang seharusnya dimiliki oleh setiap individu.

Mike Robbins (2007) menyebutkan bahwa penerimaan diri adalah sebuah aspek pokok dalam perjalanan menuju pengharagaan diri dan kepuasan. Penerimaan juga diartikan sebagai penerimaan terhadap sesuatu sebagaimana adanya dan berdamai dengan apa yang sudah diterimanya tersebut. ${ }^{1}$ Hal ini sebagaimana pendapat Endra K. Prihadhi (2004: 56) bahwa menerima diri apa adanya berarti pasrah dan jujur terhadap kondisi yang dimiliki. Tidak ada yang ditutupi baik itu kekurangan atau kelebihan dengan apa adanya. ${ }^{2}$

Selanjutnya, E. B. Surbakti (2010: 59) menyatakan bahwa penerimaan diri tidak dapat dilepaskan dari intropeksi diri, pengenalan jati diri, dan kesediaan maupun kejujuran menerima diri dengan apa adanya. Adapun aspek yang kerap menggangu dalam penerimaan diri adalah identitas. Dimana seseorang tidak merasa bangga dan mengharagi identitas yang melekat pada dirinya

${ }^{1}$ Mike Robbins. Terj. Haris Priyatno. Focus on the Good Stuff: Mukjizat Bersyukur dan Bermental Positif. Jakarta: PT. Serambi Ilmu Semesta. 2007), hlm. 197.

${ }^{2}$ Endra K. Prihadhi. My Potency: Langkah-Langkah Praktis Untuk Menemukan dan Mengelola Potensi dengan Daur Aktualisasi Potensi, (Jakarta: PT. Elex Media Komputinda. 2004), hlm. 56. 
dengan berbagai alasan. Sehingga, ketika seseorang belum dapat mengenal identitas dirinya, maka selama itu pula orang tersebut tidak akan dapat menikmati kebahagian hidup. ${ }^{1}$

Sanderson dan Linehan (dalam Orsillo \& Roemer, 2005: 81) menyatakan bahwa "acceptance is the developed capacity to fully embraced whatever is in the present moment.' ${ }^{2}$ Yang artinya, acceptance adalah sebuah kapasitas kemampuan individu yang dapat dikembangkan secara maksimal guna memahami hal yang sedang terjadi pada saat ini. Berdasarkan pengertian tersebut, dapat dikatakan bahwa pada umumnya acceptance merupakan hal yang senantiasa dijumpai dalam setiap aspek kehidupan manusia dalam berbagai situasi dan kondisi. Selain itu, penerimaan diri berlaku melalui sosialisasi dengan individu lain. Sekiranya individu itu diterima oleh orang lain, dia juga akan menerima dirinya. Penerimaan diri mempengaruhi tindak tanduk individu dalam menghadapi cobaan hidup. ${ }^{3}$

Berdasarkan pendapat para ahli tersebut, dapat disimpulkan bahwa self acceptance adalah suatu sikap dimana individu mampu menerima serta mengelola secara baik akan segala kelebihan, kekurangan dan keterbatasan yang ada di dalam diri. Dimana perwujudan sikap ini dapat menuntun individu untuk menumbuhkan kepribadian serta mental yang sehat.

\section{b. Faktor - faktor yang mempengaruhi self acceptance}

Salah satu indikator dari kepribadian yang sehat adalah adanya penerimaan di dalam diri yang baik. Dengan demikian, maka menurut Hurlock, 1974 (dalam Wulandari, 2014) ada sepuluh faktor yang sekiranya membentuk self acceptance pada individu. Kesepuluh faktor tersebut adalah sebagai berikut ${ }^{4}$ :

1) Adanya pemahaman diri

Individu seyogyanya dapat mengenali dan memahami dirinya sendiri, termasuk mengenali segala kemampuan dan ketidakmampuan yang ada di dalam diri. Hal ini dapat timbul melalui beragam kesempatan individu untuk mencoba mengenali setiap kemampuan dan ketidakmampuan tersebut. Individu yang dapat memahami diri sendiri tidak hanya bergantung pada kemampuan intelektual semata. Individu tersebut juga berkesempatan untuk melakukan penemuan akan diri sendiri (self discovery). Pemahaman diri dan self acceptance berjalan beriringan antara satu sama lain. Dengan kata lain, individu yang semakin dapat memahami dirinya sendiri akan semakin mudah untuk menerima dirinya.

2) Harapan yang realistik.

Harapan yang realistik akan muncul apabila individu dapat menentukan sendiri setiap harapan yang ada dalam dirinya dan hal ini disesuaikan dengan pemahaman dan kemampuan yang memadai. Dalam mencapai suatu tujuan, harapan realistik bersifat murni dan bukan merupakan suatu arahan dari orang lain. Individu yang memiliki harapan realistik akan semakin memungkinkan individu untuk menggapai harapan tersebut. Kesempatan untuk mewujudkan harapan tersebut juga akan semakin besar. Keseluruhan proses ini akan memunculkan kepuasan dalam diri yang merupakan salah satu faktor penting dalam self acceptance.

3) Tidak adanya hambatan dalam lingkungan

\footnotetext{
${ }^{1}$ E. B. Surbakti. Gangguan Kebahagiaan dan Solusinya. (Jakarta: PT. Elex Media Komputindo. 2010), hlm. 59.

2 Susan M. Orsilo dan Lizabeth Roemer, Approaches to Anxiety : Conceptualization and Treatment, (United States of America: Springer. 2005), hlm. 81.

3 Azizi Yahaya dan Jaafar Sidek Latif. Membentuk Identiti Remaja. (Malaysia: PTS Professional Publishing. 2006), hlm. 9.

4 Antonina Pantja Juni Wulandari. Tesis. Hubungan Antara Perceived Social Support dan Self Acceptance Pada Gay Dewasa Muda, (Fakultas Psikologi: Bina Nusantara (Binus) 2014), hlm. 55.
} 
Individu yang telah memiliki harapan yang realistik perlu mendapatkan dukungan dari orang di sekitarnya. Jika individu tidak mendapatkan dukungan dari orang di sekitarnya, maka akan sulit bagi individu tersebut untuk menggapai harapan tersebut.

4) Sikap sosial yang mendukung

Sikap-sikap anggota kelompok sosial atau masyarakat sekitar tentunya dapat mempengaruhi serta membentuk sikap dan perilaku seseorang. Sikap yang terutama berpengaruh pada self acceptance seseorang adalah sikap sosial yang mendukung. Kondisi utama yang mendukung adalah tidak adanya prasangka dan adanya penghargaan akan keterampilan sosial.

5) Tidak adanya stres emosional yang kuat

Stres emosional dapat mengakibatkan berbagai gangguan, terutama gangguan fisik serta psikologis. Apabila individu mengalami stres emosional yang kuat, maka individu tersebut dapat mengalami gangguan homeostatik yang dapat menyebabkan seseorang berfungsi secara kurang efisien atau mudah lelah. Sebaliknya, apabila kondisi emosional individu baik, maka individu tersebut akan mampu untuk bekerja sebaik mungkin serta merasakan kebahagiaan di dalam diri. Dengan tidak adanya stres emosional yang kuat, maka individu cenderung berorientasi pada aktivitas atau kegiatan yang bersifat positif sehingga dapat memunculkan rasa santai dan berbahagia. Kondisi ini secara tidak langsung memberi sumbangsih yang cukup signifikan terhadap evaluasi sikap kelompok sosial yang mendukung serta memperkuat dasar self acceptance.

6) Dampak keberhasilan yang dialami

Keberhasilan yang dialami oleh individu dapat menimbulkan self acceptance. Namun, keberhasilan yang berlebihan atau harapan yang tidak realistik dapat mengakibatkan self acceptance yang tidak sehat. Sebaliknya, jikalau individu mengalami kegagalan, maka hal tersebut dapat berujung pada penolakan diri.

7) Identifikasi dengan orang lain yang memiliki penyesuaian diri yang baik.

Individu yang mengidentifikasikan diri dengan orang lain yang memiliki tingkat penyesuaian diri yang baik cenderung membangun sikap-sikap positif terhadap diri sendiri. Dengan demikian, individu yang bersangkutan akan memunculkan perilaku yang baik pula. Hal ini pada akhirnya dapat menimbulkan penilain diri serta self acceptance yang baik.

8) Perspektif diri

Perspektif diri dapat dikembangkan dengan cara menerima serta memperhatikan setiap pandangan yang berasal dari orang lain tentang diri individu yang bersangkutan. Individu yang mampu melihat diri sendiri dalam sudut pandang orang lain yang melihatnya akan mempunyai pemahaman diri yang lebih baik. Perspektif diri yang luas dapat diperoleh melalui hasil interaksi antara pengalaman dan pembelajaran. Usia serta tingkat pendidikan tentunya memiliki peranan yang sangat penting bagi individu untuk dapat mengembangkan sudut pandang mengenai dirinya sendiri. Perspektif diri memudahkan individu untuk melakukan self acceptance dalam setiap situasi sosial yang dihadapi.

9) Peranan pola asuh pada masa kanak-kanak

Individu yang berkesempatan mendapatkan pola asuh tipe demokratis cenderung berkembang menjadi pribadi yang lebih menghargai diri sendiri. Pola asuh serta didikan yang demokratis menimbulkan pola kepribadian yang lebih sehat jika dibandingkan dengan didikan yang otoriter atau terlalu permisif. Pola asuh yang demokratis menyatakan bahwa anak harus 
dihargai sebaik mungkin. Sejak dini, anak dapat diberikan pemahaman mengenai peraturan yang ada di sekitar mereka. Setelah itu, setiap anak diberikan kesempatan untuk belajar memikul tanggung jawab, kesempatan untuk mengontrol tingkah laku yang dilakukan agar sekiranya sesuai dengan aturan-aturan yang telah diberlakukan. Hal ini dapat menyokong anak untuk mengembangkan pribadi yang menghargai diri sendiri. Pada akhirnya, pribadi yang demikian dapat berkembang serta bermuara pada self acceptance yang lebih baik.

10)Konsep diri yang stabil

Individu dengan konsep diri yang stabil akan lebih mampu untuk mengembangkan self acceptance yang lebih baik apabila dibandingkan dengan individu yang memiliki konsep diri yang cenderung tidak stabil. Individu dengan konsep diri yang tidak stabil akan sulit untuk menunjukkan pada orang lain mengenai dirinya sendiri. Hal ini dikarenakan individu tersebut juga merasakan suatu keadaan ambivalen terhadap dirinya sendiri.

Selanjutnya, self acceptance merupakan adalah salah satu hal yang paling berkonstribusi untuk mencapai kebahagiaan. Dalam mencapai kepuasaan serta kebahagiaan di dalam hidup, individu tidak hanya semata-mata perlu untuk menerima diri sendiri, tetapi juga perlu merasa diterima oleh orang lain. Penjelasan mengenai faktor-faktor self acceptance dapat memberikan gambaran tentang seberapa baik terbentuknya self acceptance seseorang. Keseluruhan faktor diatas juga mencakup faktor intrinsik serta faktor ekstrinsik. Hal ini dikarenakan perkembangan kepribadian setiap individu selalu terkait dengan kedua faktor tersebut. Baik faktor yang berasal dari dalam diri serta faktor yang berasal dari lingkungan.

\section{c. Pembentukan self acceptance}

Johnson (dalam Wulandari, 201) mengemukakan bahwa terdapat 5 proses pembentukan self acceptance, yaitu :

\section{1) Reflected self acceptance}

Individu cenderung membuat keputusan mengenai diri sendiri berdasarkan penerimaannya mengenai permikiran dan pandangan orang lain yang ditujukan bagi dirinya. Apabila orang lain menyukai dirinya, maka individu tersebut akan menyukai dirinya.

2) Basic self acceptance

Keyakinan individu bahwa dirinya diterima secara menyeluruh dan tanpa syarat oleh orangorang yang berada di sekitarnya. Dimensi ini menggambarkan perasaan keyakinan individu bahwa terdapat orang yang mencintai serta mengakui keberadaan dirinya. Pada dasarnya, dimensi ini merupakan dimensi yang paling berpengaruh pada self acceptance individu.

3) Conditional self acceptance

Self acceptance ini didasarkan pada seberapa baik individu mampu untuk memenuhi tuntutan dan harapan dari orang-orang yang berada di sekitarnya. Self acceptance dalam tahap ini baru akan disadari oleh individu yang bersangkutan apabila individu tersebut merasa bahwa dirinya berharga setelah berhasil memenuhi harapan orang lain terhadap dirinya.

4) Self evaluation

Penilaian individu mengenai seberapa positif berbagai atribut yang ada di dalam diri, baik atribut secara fisikal maupun psikologis. Individu akan melakukan perbandingan dengan berbagai atribut yang dimiliki oleh orang lain yang sebaya dengannya.

5) Real-ideal comparison 
Derajat kesesuaian antara pandangan individu mengenai diri yang sebenarnya dengan diri yang dicita-citakan akan membentuk rasa penghargaan terhadap diri sendiri. Setiap individu menggunakan satu atau lebih cara untuk membuat kesimpulan akan penilaian di dalam diri.

\section{Homoseksual}

\section{a. Definisi Homoseksual}

Gus Arifin (2010: 313) menyatakan bahwa homoseks adalah kata sifat yang digunkana untuk hubungan intim dan/atau hubungan seksual di antara orang-orang yang berjenis kelamin yang sama atau lebi dikenal dengan istilah gay bagi sesama laki-laki, dan lesbi bagi sesama perempuan. ${ }^{1}$ Sedangkan menurut Sunaryo (2002: 243), homoseksual adalah ketertarikan melakukan hubungan seks dengan sesama jenis (pria dengan pria atau wanita dengan wanita). Lazim disebut homoseksual apabila dilakukan antara pria dan pria, sedangkan pada wanita disebut lesbian. Kebalikan dari homo seksual adalah hetroseksual. ${ }^{2}$ Yustinus Semiun (2006), menyebutkan bahwa tingkah laku homoseksual adalah kegiatan seksual dengan mitara sejenis. Namun perlu untuk diperhatikan bahwa tidak ada dikotomi yang sederhana mengenai orang yang homoseksual dengan hetroseksual.

Penemuan-penemuan klinis menunjukkan bahwa banyak individu yang belum pernah turut serta dalam suatu kegiatan homoseksual secara terang-terangan mungkin mempunyai kecenderungan yang tersembunyi dan tak disadari, dan mungkin diungkapkan pada saluran lain dari tingkah laku homoseksual. Kinsey (dalam Yustinus, 2006) melaporkan bahwa $37 \%$ pria dan $25 \%$ wanita telah melakukan kegiatan homoseksual sampai pada titik orgasme setelah mulainya masa adolesen. Tetapi, hanya $4 \%$ dari anak laki-laki melaporkan hubungan yang benar-benar homoseksual. ${ }^{3}$

Berdasarkan beberapa pendpat tersebut, maka homoseksual dapat diartikan sebagai ketertarikan seksual primer terhadap jenis kelamin yang sama. Untuk kaum lelaki homoseksual maka istilah yang akan digunakan adalah gay sedangkan pada perempuan mereka dikenal dengan istilah lesbi. Definisi ini bukan merupakan suatu hal yang mutlak dan bersifat final. Hal ini karena adanya beberapa komponen biologi dan psikologis dari seks dan gender yang dengan itu seseorang tidak mungkin seratus persesn digolongkan dalam kategori tersebut. Bahakan beberapa diantaranya menganggap opensif prihal pembedaan gender dan pembedaan orientasi seksual.

\section{b. Faktor-faktor penyebab homoseksual}

Perilaku homo seksual bukanlah merupakan sesuatu yang bersifat alami atau dibentuk oleh suatu proses sosial budaya pada awal penciptaan manusia. Sehingga dalam hal ini ada tiga faktor utama yang melatarbelakangi terbentuknya perilaku homoseksual, yaitu faktor biologis, psikologis dan sosial budaya. Dengan kata lain sesorang menjadi pelaku homoseksual bukan merupakan takdir, melainkan sebauh kecenderungan yang dipengaruhi oleh kondisi dari ketiga faktor tersebut.

Menurut Sidik Hasan dan Abu Nsma (2002) terdapat beberapa faktor penyebab terjadinya homoseksualitas. Pertama, faktor biologis. Hal ini terjadi karena sejak lahir seseorang memiliki kelainan pada sususnan syaraf otak dan memiliki kelainan genetic atau hormonal. Sehingga, hal inin berakibat ia memiliki kecenderungan untuk tertarik terhadap orang lain yang sejenis. Kedua, faktor

${ }_{1}$ Gus Arifin. Menikah Untuk Bahagia: Fiqh tentang Pernikahan dan Kamasutra Islami, Jakarta. PT Elex Media Komputindo. 2010), hlm. 313.

2 Sunaryo, Psikologi Keperawatan, (Jakarta: Penerbit Buku Kedokteran EGC. 2002), hlm. 243.

3 Yustinus Semiun. Kesehatan Mental 2: Gangguan-gangguan Kepribadian, reaksi-reaksi Simtom Khusus, Gangguan Penyesuaian Diri Anak-Anak. Luar Biasa dan Gangguan Mental yang Berat, (Yogyakarta: Penerbit Kanisius. 2006), hlm. 44. 
psikologis. Hal ini misalnya terjadi akibat pengalaman masa lalu indvidu yang pernah menjadi korban sodomi di saat masih kecil, atau ia pernah mencoba-coba untuk melakukan hubungan seks sejenis dengan teman-temannya. Selain itu, faktor psikologis ini bisa berupa kondisi dimana seorang perempuan atau laki-laki tidak diperlakukan sebagaimana jenis kelaminnya. Hal ini lama kelamaan mempengaruhi kecenderungan orientasi seksualnya dimasa yang akan datang. Ketiga, faktor lingkungan. Faktor ini muncul sebagai reaksi masyarakat terhadap perilaku homoseksual yang berubah-ubah seiring perkembangan zaman. Misalnya dengan berkembangnya budaya demokrasi yang pada akhirnya memberikan kebebasan memilih pasangan dengan cara yang melampaui batas, gencarnya web site yang menampilkan video dan gambar porno, serta belum adanya sanksi tegas terhadap pelaku homoseksual.

\section{c. Tahap perkembangan identitas homoseksual}

Perkembangan identitas seksual pada kaum homoseksual laki-laki (gay), terbagi ke dalam 6 priode atau tahapan, di antaranya : 1) Identity Confusion - pada tahap ini, seseorang mulai merasa tidak nyaman dengan keadaan hetroseksual yang dialaminya, ia mulai mempertanyan kenapa dirinya berbeda dengan orang lain (difference) dan bertanya "siapakah aku dan bagaimana ?". 2) Identity Comparison - pada tahapan ini, seseorang mulai merasa mengenal dirinya sendiri sebagai bagian dari kaum homoseksual dan merasa nyaman dengan identitasnya yang baru. Biasanya diawali dari perenungan, menyendiri di kamar ataupun mencari kebenaran bukan kepada orang yang tepat dan dapat mengembalikannya pada jalan yang benar. Hal ini ditandai dengan ungkapan "Saya mungkin adalah homoseksual". 3) Identity Tolerance - pada tahapan ini seseorang mulai merasa yakin apa yang menjadi pilihannya adalah hal yang tepat, hal ini ditandai dengan sebuah pernyataan 'Saya rupanya adalah homoseksual". Selain itu, pada masa ini seseorang mulai menjalin kontak lebih dalam dengan pelaku homoseksual dan mulai aktif dalam berbagai aktifitas kaummnya. 4) Identity Acceptance - pada tahapan ini seseorang mulai berkomitemen bahwa "Saya adalah homoseksual", dia sudah menerima apa yang ada pada dirinya sebagai sebuah hal yang wajar. Pada beberapa kasus, ada individu yang merasa bahwa dirinya terjebak dalam anggota tubuh yang bukan seharusnya ditempati. 6) Identity Pride, pada tahapan ini, sesesorang homoseks mulai memiliki identitas bahwa "mereka bukan bagian dari saya", sehingga mereka menggap orang yang tidak seperti mereka bukanlah bagian dari mereka. Identifikasi ini menghasilkan sikap eksklusif dimana keterbukaan komunikasi seksual hanya pada kaumnya dan bukan pada yang lain. 7) Identity Synthesis. Pada tahapan terakhir ini, seseorang tidak lagi memisahkan antara kaum homoseksualitas dan heteroseksualitas. Keadaan ini merupakan situasi final dimana tidak ada lagi kemungkinan pelaku homoseksual akan kembali ke keadaaan semula sesuai dengna kodrat dan jenis kelaminnya. Biasanya status ini akan dibawa oleh individu sampai mati.

\section{PERAN AYAH DALAM PERKEMBANGAN ANAK}

1. Peran Ayah dalam Pendidikan Anak

Adnan Hasan Shalih (1996: 29) menyebutkan bahwa ayah memiliki kedudukan yang penting dan mulia. Ayah adalah kepala keluarga yang memimpin ibu, anak-anak dan pelayan. Ayah bertanggung jawab terhadap mereka dan akan diminta pertanggung jawabannya oleh Allah SWT sebagaimana dalam hadits Rasulullah SAW,

${ }^{1}$ Adnan Hasan Shalih Baharits. Tanggung Jawab Ayah Terhadap Anak Laki-laki, Jakarta: Gema Insani Press. 1996), hlm. 


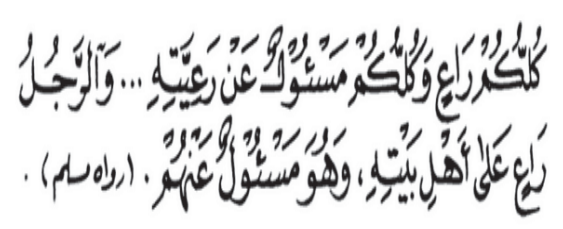

Artinya:

"Setiap kamu adalah pemimpin, dan setiap kamu akan dimintai pertanggungjawaban terbadap apa yang kamu pimpin. Seorang suami (ayah) adalah pemimpin bagi anggota keluarganya, dan ia akan dimintai pertanggungjawaban terbadap apa yang telah dipimpinnya atas mereka."

Berdasarakan hadits tersebut, tanggung jawab ayah salah satunya adalah sebagai pemimpin yang memikul beban pembentukan generasi Islam selanjutnya yang saleh. Selain itu, ayah juga bertanggung jawab dengan apa yang dipimpinnya dan akan dimintai pertanggunjwabanaya. Selanjutnya menurut Imas Kurniasih (2010: 81 - 82). Ada dua tugas seorag ayah yang berkenaan dengan anaknya, Pertama, seorang ayah harus memberikan anaknya ibu yang baik, dalam hal ini seorang calon ayah harus dapat menikah dengan wanita yang sesuai dengan kriteria syariat Islam. Kedua, memberikan anaknya lingkungan yang baik, dalam hal ini lingkungan yang kondusif dan tetangga yang baik turut berperan dalam menciptakan pribadi yang baik. ${ }^{1}$

Menurut Nasriul Effendy (1998) peran ayah dalam keluarga adalah sebagai suami dari isteri dan anak-anak, berperanan sebagai pencari nafkah, pendidik, pelindung dan pemberi rasa aman, sebagai kepala keluarga, sebagai anggota dari kelompok sosialnya serta sebagai anggota masyarakat dari lingkungannya. ${ }^{2}$ Atau dalam keluarga kedudukan ayah adalah sebagai kepala rumah tangga.

Menurut Sylvia Rimm (2003: 102), peran ayah dalam keluarga telah berubah dramatis dari generasi yang lalu dan lebih lagi dibandingkan dengan generasi kakek-kakek kita. Perubahan tersebut biaanya menyenangkan bagi para ibu dan juga para ayah itu sendiri. Meski para ayah tidak menagndung bayi mereka. Malahan biasanya mereka mengatakan, "kami akan punya anak." Bukan mengatakan, "isteri saya akan punya anak." Selama kehamilan dan persalinan ayah juga mempersiapkan diri dan member dukungan serta semangat kepada para ibu. Hasil dari hal tersebut, terciptalah ikatan yang tak terlupakan dan terbentuklah tim yang kuat. ${ }^{3}$

2. Ayah dan Perilaku Homoseksual

Ayah merupakan salah satu faktor penentu perkembangan anak, selain dari ibu yang berperan mengasuh, menjaga, memberikan afeksi, rangsangan dan pendidikan. Menurut Reni Akbar-Hawadi (2001: 15) tugas seorang ayah secara tradisional adalah melindungi keluarga (protection) dan mencari nafkah (breadwinning) namun kemudian diperluas dalam hal-hal yang menyangkut child management dan pendidikan. ${ }^{4}$ Pada lingkungan keluarga tradisional ayah biasanya membuat dan menegakkan aturan yang menjadi tradisis dalam keluarga.

${ }^{1}$ Imas Kurniasih, Mendidik SQ Anak Menurut Nabi Muhammad SAW, (Yogyakarta: Penerbit Pustaka Marawa. 2010), hlm 81-82.

2 Nasrul Effendy, Dasar-Dasar Keperawatan Kesehatan Masyarakat, Jakarta: Penerbit Buku Kedokteran EGC. 1998), hlm. 34.

3 Sylvia Rimm, Mendidik dan Menerapkan Disiplin Pada Anak Prasekolah, Jakarta: PT. Gramedia Pustaka Utama. 2003), hlm. 102.

${ }^{4}$ Reni Akbar Hawadi, Psikologi Perkembangan Anak: Mengenal Sifat, Bakay dan kemampuan Anak, (Jakarta: PT. Gramedia Widiasarana Indonesia. 2001), hlm. 15. 
Melalui sikap otoritas dan disiplin, ayah merangsang orientasi realitas berpikir anak. Termasuk memberikan beban pada masing-masing anggota keluarga untuk hidup secara realistis. Hal ini berbeda dengan kecenderungan sikap seoarang ibu yang memberikan kesenangan pada keinginan anak untuk dapat mendorong anaknya.

Pada keluarga yang hidup dengan wajar. Ayah dan ibu bekerjasama dalam satu kesatuan perawatan anak. Ayah dan ibu memberikan kasih sayang yang sama, kepada anak lakilaki dan anak perempuan. Melalui hubungan segitiga ini, anak laki-laki akan beridentitas dengan ayah sebagai tokoh pria dewasa, dan anak perempuan dengan ibu sebagai tokoh wanita dewasa. Dengan terselesaikannya hubungan segitiga tersebut, maka anak perempuan akan berindentifikasi dengan ibunya, dan anak laki-laki dengan ayahnya (indentitas seksual dan indentitas diri).

Kalau ibu terlalu dominan pengaruhnya, sedangkan ayah kurang tegas atau ayah tidak ada (absen), baik secara fisik maupun kejiwaan, maka akan terjadi proses identifikasi (proses meniru) yang salah. Anak laki-laki akan beridentifikasi dengan ibunya, sehingga lebih mengembangkan sifat-sifat perempuan. Ia lebih senang bermain boneka atau masak-masakan, sehingga berpengaruh kelak terhadap jati dirinya yang secara biologis laki-laki, tetapi secara psikologis perempuan. Atau kelak ia akan mecari calon isteri yang mirip ibunya yang dapat mengasuhnya. Atau ia menjadi lakilaki yang memiliki kekuatan ego lemah, sehingga mudah dikendalikan oleh faktor-faktor luar, dan selalu teromabng ambing oleh berbagai situasi pilihan, tandapa dapat mengambil keputusan yang baik dan benar bagi dirinya.

Sebaliknya, jika ibu bersikap cerewet, dan kurang dekat dengan anak perempuannya, maka anak cenderung beridenntifikai dengan ayahnya, dan lebih mengembangkan sikap kelakilakian (tomboy), sehingga lebih senang memanjat pohon main layanngan, atau mobil-mobilan, sehingga kelak ia akan menjadi wanita yang cenderung dingin, keras, ambisius, sulit mendapatkan pasangan atau berganti-ganti pasxangan, sebab tidak pernah mendapat kepuasan . atau ia mencari pasangan yang dapat menjadi penggati ayahnya.

Anak pada usia ini mulai menyadari bahwa ada perbedaan antara alat kelamin laki-laki dan perempuan. Anak mulai mengenal identitas dirinya bukan hanya dari alat kelamin yang dimilikinya tetapi juga perlakuan sekeliling mereka. Anak perempuan akan mendapatkan mainan seperti bonea atau alat-alat masak-masakan, sedangkan anak laki-laki mendapatkan mainan mobil-mobilan ataupun pesawat-pesawatan. Anakpun mulai merasakan secara psikologis penagaruh dari jenis kelaminnya. Anak laki-laki cenderung menjadi lebih sayang pada ibunya. Sebaliknya, anak perempuan lebih sayang pada ayah. Anak-anak mulai mempunyai keinginan ingin seperti ayah atau ibunya kelak. ${ }^{1}$

Yustininus Semiun (2006: 82) menyatakan bahwa salah satu penemuan yang jelas dan konsisten bahwa individu yang mengalami gangguan identitas gender memperlihatkan pola-pola tingkah laku dari lawan jenis kelaminnya. Banyak penelitian telah membuktikan bahwa pada waktu masih kanak-kanak, pria digambarkan sebagai "banci" (pria kewanita-wanitaan) yang lebih suka memilih kegiatan wanita, dan wanita digambarkan sebagai "tomboy" (wanita yang kelaki-lakian) yang lebih menyukai kegiatan pria. Fakat bahwa gangguan identitas gender kelihatan pada masa kanak-kanak terungkap dalam DSM III-R, diamana gangguan ini didaftar pada bagian tentang "disorders usually first evident in infancy, childhood, or adolescence" dan bukan pada bagian tentang "sexsual disorders."

1 Chairinniza Graha, Keberhasasilan Anak di Tangan Orang Tua: Panduan Bagi Orang Tua Untuk Memahami Perannya dalam Membantu Keberhasilan Pendidikan Anak, (Jakarta: PT. Elex Media Komputindo. 2007), hlm. 25. 
Dalam mempertimbangkan gangguan ini yang muncul sejak awal kehidupan, maka penting diketahui bahwa mekipun semua orang dewasa yang mengalami gangguan identitas gender adalah banci atau tomboy dalam masa kanak-kanak, namun tidak semua anak yang banci atau tomboy akan tetap mengalami gangguan identitas gender bila mereka menjadi dewasa. Dengan alasan ini tidak dapat diasumsikan bahwa seorang anak yang memiliki minat dan ciritingkah laku dari lawan jenis memperlihatkan tanda-tanda awal gangguan identitas gender.

Penemuan bahwa simtom-smtom gangguan identitas gender yang pada awalnya kelihatan pada masa kanak-kanak telah menghasilkan asumsi dari beberapa teoritikus bahwa gangguan itu disebabkan oleh latihan dalam peran gender yang tidak tepat dalam awal masa kanak-kanak. Secara khusus telah dikemukakan bahwaorangtua atau orang dewasa lain mungkin mempercepat perkembangan tingkah laku lawan jenis, dan ada kemungkinan mereka menginginkan anak dari jenis kelamin lain. Ayah menginginkan seorang anak laki-laki mungkin memperlakukan anak perempuannya sperti anak laki-laki, membawanya untuk bermain sepakbola atau kekantor, dan dengan demikain mengajarnya untuk menjadi anak laki-laki. ${ }^{1}$

Papalia et.al., (2009) mengemukakan bahwa batasan usia untuk tahap perkembangan usia dewasa muda adalah usia 20-40 tahun. Tahap perkembangan usia dewasa muda terdiri dari tiga bagian utama, yaitu perkembangan fisik, perkembangan kognitif dan perkembangan psikososial. Perkembangan fisik ditandai dengan kesehatan individu yang juga dikaitkan dengan pola gaya hidup individu. Perkembangan kognitif ditandai dengan cara berpikir serta penilaian moral individu yang semakin kompleks, dimana pada tahapan ini individu diharuskan untuk melakukan pengambilan keputusan yang bersifat krusial bagi kehidupannya di masa mendatang. Pengambilan keputusan ini mencakup hal yang terkait dengan pendidikan maupun pekerjaan.

Dalam perkembangan psikososial, individu dewasa muda dihadapkan pada isu perkembangan seperti perlunya menjalin hubungan intim, pemilihan gaya hidup, menikah atau menjadi orang tua. Tugas perkembangan individu dewasa muda adalah menemukan jati diri, menjadi individu yang mandiri, memiliki ketegasan akan prinsip-prinsip yang dianut serta membangun hubungan romantis dengan individu lain. Menurut Erikson (Papalia et.al., 2007) tugas utama individu pada usia dewasa muda ialah membangun hubungan intimasi dengan orang lain. Intimasi yang dimaksud disini bukan hanya sekedar kedekatan secara seksual, namun adanya perasaan memiliki serta adanya emosi positif dalam diri.

Menurut Papalia, et.al., (2009) dewasa muda memerlukan teman untuk saling berbagi pengalaman tentang karir dan pekerjaan. Selain itu dengan memiliki teman, maka individu akan memiliki perasaan positif tentang dirinya (Papalia et.al, 2009). Baumeister dan Myers (dalam Papalia et.al., 2009) juga mengemukakan bahwa orang yang sehat secara fisik dan mental akan hidup lebih lama apabila kondisi hubungan dengan orang terdekatnya terpuaskan. Individu dewasa muda akan berusaha untuk mendapatkan keintiman emosional dan fisik di dalam hubungan pertemanan serta hubungan romantic yang dijalani. (Papalia et.al, 2009). Sama seperti kaum heteroseksual, kaum homoseksual juga mencari hubungan romantis dengan seseorang untuk mencari cinta, persahabatan dan pemenuhan kebutuhan seksual.

Menurut Greene dan Croom (2000) isu-isu perkembangan yang dihadapi oleh kaum homoseksual usia dewasa muda adalah mengenai keputusan kaum homoseksual apakah ingin melakukan coming out atau tidak, apakah individu akan menikah (terikat pernikahan heteroseksual),

1 Yustinus Semiun, Kesehatan Mental 2: Gangguan-gangguan Kepribadian, reaksi-reaksi Simtom Khusus, Gangguan Penyesuaian Diri Anak-Anak Luar Biasa dan Gangguan Mental yang Berat, (Yogyakarta: Penerbit Kanisius. 2006), hlm. 82. 
menjalin hubungan dengan sesama jenis, melakukan pernikahan dengan lawan jenis tetapi tetap mempunyai pasangan sesama jenis atau hidup melajang. Isu perkembangan kaum homoseksual dewasa muda tentunya membawa tantangan tersendiri untuk kehidupan kaum homoseksual. Lefkowitz dan Gillen (dalam Papalia et.al., 2009) juga menyatakan bahwa bagi kebanyakan gay, lesbian, biseksual, transgender yang berada pada usia dewasa muda telah memiliki keyakinan atas identitas seksual yang dimiliki.

Pada Gambar 2.1 terdapat kerangka berpikir peneliti yang melatarbelakangi dilaksanakannya penelitian ini. Hal yang melandasi penelitian ini adalah adanya data yang menunjukkan bahwa terdapat sejumlah besar kaum gay yang berada di Indonesia. Menurut data yang dilansir dalam portal Gaya Nusantara (Oetomo, 2006), Oetomo mengatakan bahwa jumlah kaum gay di Indonesia sudah mencapai 20.000 .000 orang Sedangkan, hasil survei Yayasan Pelangi Kasih Nusantara (YPKN) juga menunjukkan bahwa terdapat 4.000 - 5.000 penyuka sesama jenis di Jakarta. Jumlah tersebut bersifat fluktuatif, karena diyakini dapat semakin meningkat. Perdebatan akan keberadaan kaum homoseksual seringkali memunculkan sikap negatif dari lingkungan sosial. Kebanyakan kaum homoseksual mengalami sikap diskriminatif dan penganiayaan akibat sikap negatif yang ditunjukkan oleh masyarakat. Akan tetapi, sikap negatif serta diskriminasi pada homoseksual lebih ditujukan kepada gay daripada lesbian (Hyde, 2008).

Walaupun demikian, kaum gay secara perlahan semakin menunjukkan eksistensinya. Terbukanya kaum gay ini dapat dilihat dari adanya suatu perkumpulan atau komunitas tertentu yang disediakan bagi kaum homoseksual. Selain itu, perlu diketahui juga bahwa pergerakan dukungan serta perlindungan bagi kaum LGBT juga semakin berkembang di Indonesia (Suvianita, 2013). Menurut Kimmel and Sang (1995) (dalam Taylor, Peplau dan Seras 2006), generasi masa kini secara inheren mulai berusaha menjelajahi berbagai ragam kesempatan untuk menumbuhkan penerimaan akan homoseksualitas. Hal ini mungkin dapat disebabkan oleh jumlah kaum gay yang semakin meningkat.

Berdasarkan keseluruhan hal tersebut, dapat diketahui bahwa terdapat beragam reaksi yang ditimbulkan oleh masyarakat terhadap keberadaan gay baik pro maupun kontra. Namun, sebagai makhluk sosial kaum gay juga memerlukan social support dari masyarakat sekitar. Setiap individu di dalam setiap siklus kehidupannya memerlukan dukungan dari orang di sekitarnya. Social support akan semakin dibutuhkan pada saat seseorang sedang mengalami masalah atau sedang mengalami masa sulit. Seperti yang telah diketahui, gay dewasa muda cenderung mengalami masa sulit terkait dengan orientasi seksual yang dimilikinya.

Social support yang diterima oleh individu tidak dapat secara langsung berimplikasi pada kehidupan individu. Hal ini dikarenakan persepsi terhadap dukungan yang diterima oleh individu yang bersangkutan bisa saja berbeda. Sarason et.al., (1983) menyatakan bahwa cara individu mempersepsikan social support merupakan inti utama dari social support yang tersedia bagi individu. Hal ini dikarenakan cara individu menilai dukungan yang tersedia bagi dirinya merupakan suatu hal yang jauh lebih penting daripada interaksi interpersonal yang sesungguhnya dilakukan. Persepsi terhadap social support yang diterima oleh kaum gay mengartikan bahwat terdapat suatu penilaian yang diberikan oleh kaum gay tersebut akan social support yang diterima.

Persepsi terhadap social support yang diterima oleh gay dewasa muda melibatkan dua hal, yaitu bagaimana individu mempersepsikan bahwa ada orang yang bersedia membantu di saat yang membutuhkan serta seberapa puas individu yang bersangkutan akan bantuan tersebut, terutama dari orang-orang yang dianggap sebagai significant others. Singkatnya, persepsi individu akan 
dukungan sosial yang diterima dapat dibedakan menjadi dua bagian yaitu berdasarkan jumlah orang yang mendukung (number) serta derajat kepuasan (satisfaction). Ketika individu yang bersangkutan mempersepsikan bahwa terdapat dukungan sosial dari sejumlah orang di sekitarnya yang mampu menolong atau membantu dirinya, maka individu akan memiliki perasaan adanya penerimaan dari lingkungan. Perasaaan adanya penerimaan dari lingkungan akan memicu individu untuk merasakan bahwa dirinya dapat diterima. Perasaan diterima akan menimbulkan perasaan bahwa dirinya berharga, sehingga individu yang bersangkutan akan dapat menerima dirinya dengan lebih baik. Selain itu, setiap social support yang dipersepsikan diterima oleh individu yang bersangkutan akan menimbulkan suatu penilaian. Penilaian ini berupa derajat kepuasan individu akan dukungan sosial yang dipersepsikan diterima oleh individu yang bersangkutan. Derajat kepuasan ini tentunya bergantung pada ragam situasi dan kondisi yang sedang dihadapi oleh individu yang bersangkutan, dimana semakin tinggi derajat kepuasan yang dirasakan oleh individu maka individu akan semakin menerima diri.

\section{PENUTUP}

Berdasarkan berbagai penjelasan di atas, maka orang tua yang dalam hal ini terutama adalah ayah, memiliki peranan yang penting dalam membentuk perilaku anak menjadi lakilaki atau perempuan. Pola asuh yang keliru dalam mendidik anak akan berpengaruh pada perilaku anak dimasa yang akan datang. Sehingga dalam keluarga tidak hanya ibu, ayah juga hendaknya mampu menampilkan perilaku sesuai dengan jenis kelaminnya.

\section{REFRENSI}

Adnan Hasan Shalih Baharits. 1996. Tanggung Jawab Ayah Terhadap Anak Laki-laki. Jakarta: Gema Insani Press.

Antonina Pantja Juni Wulandari. 2014. Tesis. Hubungan Antara Perceived Social Support dan Self Acceptance Pada Gay Dewasa Muda.Fakultas Psikologi: Bina Nusantara (Binus).

Azizi Yahaya dan Jaafar Sidek Latif. 2006. Membentuk Identiti Remaja. Malaysia: PTS Professional Publishing.

Chairinniza Graha. 2007. Keberhasasilan Anak di Tangan Orang Tua: Panduan Bai Orang Tua Untuke Memahami Perannya dalam Membantu Keberhasilan Pendidikan Anak Jakarta: PT. Elex Media Komputindo.

E. B. Surbakti. 2010. Gangguan Kebahagiaan dan Solusinya. Jakarta: PT. Elex Media Komputindo.

Endra K. Prihadhi. 2004. My Potency: Langkah-Langkah Praktis Untuk Menemukan dan Mengelola Potensi dengan Daur Aktualisasi Potensi. Jakarta: PT. Elex Media Komputinda.

Gus Arifin. 2010. Menikah Untuk Bahagia: Fiqh tentang Pernikahan dan Kamasutra Islami. Jakarta. PT Elex Media Komputindo.

Imas Kurniasih. 2010. Mendidik SQ Anak Menurut Nabi Mubammad SAW. Yogyakarta: Penerbit Pustaka Marawa.

Mike Robbins. 2007. Terj. Haris Priyatno. Focus on the Good Stuff: Mukjizat Bersyukur dan Bermental Positif. Jakarta: PT. Serambi Ilmu Semesta. 
Nasrul Effendy. 1998. Dasar-Dasar Keperawatan Kesehatan Masyarakat. Jakarta: Penerbit Buku Kedokteran EGC.

Reni Akbar Hawadi. 2001. Psikologi Perkembangan Anak: Mengenal Sifat, Bakay dan kemampuan Anak. Jakarta: PT. Gramedia Widiasarana Indonesia.

Sunaryo. 2002. Psikologi Keperawatan. Jakarta: Penerbit Buku Kedokteran EGC.

Susan M. Orsilo dan Lizabeth Roemer. 2005. Approaches to Anxiety : Conceptualization and Treatment. United States of America: Springer.

Sylvia Rimm. 2003. Mendidik dan Menerapkan Disiplin Pada Anak Prasekolah. Jakarta: PT. Gramedia Pustaka Utama.

Yustinus Semiun. 2006. Kesehatan Mental 2: Gangguan-gangguan Kepribadian, reaksi-reaksi Simtom Khusus, Gangguan Penyesuaian Diri Anak-Anak Luar Biasa dan Gangguan Mental yang Berat. Yogyakarta: Penerbit Kanisius. 